\title{
The effect of relocation on milk removal in primiparous dairy cows reared in different rearing systems during the early postnatal period
}

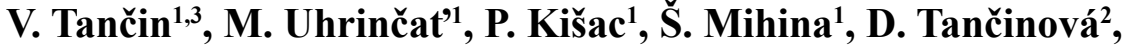 \\ A. Hanus ${ }^{1}$, D. Peškovičová ${ }^{1}$ and J. Brouček ${ }^{1}$
}

\author{
${ }^{1}$ Research Institute of Animal Production \\ Hlohovska 2, SK - 94992 Nitra, Slovak Republic \\ ${ }^{2}$ Slovak University of Agriculture \\ Tr. A. Hlinku 2, SK - 94976 Nitra, Slovak Republic
}

(Received 13 November 2002; revised version 7 November 2003; accepted 14 January 2004)

\begin{abstract}
The aim of the experiment was to determine whether different rearing systems for dairy calves before weaning could later influence their response to change of milking place in maturity, i.e. to milking in an unknown place. During the pre-experimental period, 96 primiparous Holstein calves were reared in three different housing systems (32 in each group) before weaning at 60 days. The first group was reared in loose housing and fed by an automatic milk replacer drinker, the second group was reared in individual hutches, the third was kept in loose housing with nursing cows during the first two months of life. After weaning all calves were reared under the same housing and feeding conditions in a loose housing barn. Then 33 of them (13 from the first group, 12 from the second, and 8 from the third) were used for the experiment as lactating dairy cows. After morning milking the cows were relocated from the loose housing where they were milked in the parlour to tie housing and milked in the stall. The parameters of both systems of milking were similar. The volume of milk recorded in the first three min of milking was reduced during the first evening and following morning milking after relocation $(\mathrm{P}<0.05)$. Furthermore, the negative effect of relocation was stronger in the group reared under nursing cows as compared with the two other groups, but only during the first evening milking $(\mathrm{P}<0.05)$. In conclusion, relocation delayed the commencement of milk ejection. The commencement of milk ejection of cows can be postponed if the type of their housings during early postnatal period is taken into account.
\end{abstract}

KEY WORDS: dairy cows, rearing systems, relocation, milking

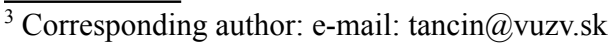




\section{INTRODUCTION}

The milk removal process in dairy cows is negatively influenced by many factors in dairy practice (Tančin and Bruckmaier, 2001). These factors can influence milk removal at central (inhibition of pituitary oxytocin release) and peripheral levels (inhibition of oxytocin effect in the udder) (Bruckmaier and Blum, 1998). The central disturbances are the main reasons for milk removal problems in dairy practice, however, the mechanisms involved are not understood in dairy cows (Tančin and Bruckmaier, 2001).

The change of the milking environment is one of the negative factors influencing milk removal (Bruckmaier et al., 1993; Tančin at al., 2001). However, there is high individual variability in milk removal efficiency during milking in a new milking place (Tančin et al., 2000). The development of responses to stress is dependent on the early experiences of infant rats (Zimmerberg et al., 2003).

The aim of the present experiment was to determine whether different rearing systems for calves in the early postnatal period could influence milk removal in response to an unknown milking place in maturity.

\section{MATERIAL AND METHODS}

\section{Pre-experimental period}

The experimental cows (96) were differently reared as calves (three housing systems, 32 per group) during their first two months after birth until they were weaned. The calves in the first group were reared in a loose housing system and fed by an automatic milk replacer drinker from which they received $6 \mathrm{~kg}$ of milk replacer per day divided into 4 portions in $6 \mathrm{~h}$ intervals. In the second group the calves were reared in individual hutches and fed with $6 \mathrm{~kg}$ of milk replacer per day from a bucket with a nipple, the replacer was divided into 2 portions in $12 \mathrm{~h}$ intervals. The animals in the third group were kept in loose housing with nursing cows. The number of calves per nursing cow was determined according to their milk yield ( $6 \mathrm{~kg}$ milk per calf). The calves could eat starter mixtures and lucerne hay ad libitum until weaning $(60 \mathrm{~d})$. They received $1.5 \mathrm{~kg}$ of concentrate mixture per $\mathrm{d}$ and lucerne hay offered ad libitum from weaning to $180 \mathrm{~d}$. From the age of $90 \mathrm{~d}$ they received maize silage. From day 181, all heifers were fed the same diet according to Slovakian recommendations for intake of dry matter to attain 0.75 $\mathrm{kg}$ average daily gain and were housed in loose housing with straw bedding until parturition (Brouček et al., 1999, 2000).

After parturition in individual maternity pens the cows joined the production herd on day 7 and were milked in a herringbone parlour $2 \times 5$ stalls with vacuum 
level $50 \mathrm{kPa}$, pulsation rate 55 c. p.m. and pulsation ratio 60:40. The cows were milked twice a day at 05.00 and $16.00 \mathrm{~h}$. The udder preparation for milking consisted of fore-stripping and cleaning. A milking cluster was attached to the udder within $1.5 \mathrm{~min}$ of the beginning of udder preparation. The cows had free access to a mixed ration providing energy and nutrients for the production of $20 \mathrm{~kg}$ milk and received additional concentrates depending on their milk production $(0.45 \mathrm{~kg}$ concentrates per kilogram milk).

\section{Experiment}

Only available primiparous dairy cows reared differently as calves that were in the middle of lactation (months 2 to 4 ) were chosen for the experiment. Thirteen cows from the first group were selected (feeder group), twelve from the second (hutches group), and eight from the third (nursed group). The cows were relocated after the morning milking to a tie housing barn where they were milked in the stall at the regular milking time (milking in an unknown place). The parameters of the milking system, udder preparation, milkers and feeding ration were the same as before relocation.

Two days before the relocation (control data) and at the first, second, fifth and sixth milking after relocation the milk yield was recorded by Tru-test (Thru-Test Limited, New Zealand) installed into the milking system during the evening and morning milkings. The first and fifth milkings represent evening measurements, second and sixth milkings represent morning measurements. The total milk yield, time of milking and amount of milk in the first three min of milking were recorded by the observer in the Tru-test cylinder.

\section{Statistical methods}

SAS statistical software - procedure MIXED (SAS, ver. 8.2, 2001) was used for statistical analyses. A linear model with fixed and random effects was used to model the studied traits. Morning and evening measurements were analysed separately. The statistical model can be written in the following form:

where

$$
y_{i j k}=R E L(H O U S I N G)_{j: i}+\operatorname{cow}_{k}+e_{i j k}
$$

$y_{i j k}$ - the measurements: time of milking, total yield, yield in first three minutes during morning and evening milking

REL(HOUSING) $)_{j: I}$ - the fixed effect of $\mathrm{j}^{\text {th }}$ housing within $\mathrm{i}^{\text {th }}$ relocation $(\mathrm{i}=1, \ldots, 3$, $\mathrm{j}=1, \ldots 3)$

cow $_{k}$ - random effect of cow, cow $\sim \mathrm{N}\left(0, \mathrm{I}_{\mathrm{c}}^{2}\right),(k=1, \ldots, 33)$

$e$ - random error, assuming $\mathrm{e} \sim \mathrm{N}\left(0, \mathrm{I} \sigma_{\mathrm{e}}^{2}\right)$. 
Differences between the levels of the relocation within type of housing were tested by the Scheffe multiple range test for the studied traits. In tables, the data are presented as least square means (lsmeans) and standard error.

\section{RESULTS}

The average milk yield per day before relocation was $19.7 \pm 0.6 \mathrm{~kg}$. On the first day after relocation the milk yield was slightly reduced $(19.1 \pm 0.6)$ but significantly increased on the fifth day $(21.1 \pm 0.2 \mathrm{~kg})$. There was a significant negative effect of relocation on the efficiency of milk removal: volumes of milk obtained during the first three min of milking after relocation were lower than before or on the fifth day after relocation (Table 1). Time of milking was significantly prolonged by relocation.

The effect of relocation within the differently reared groups of animals is presented in Table 2. A significant effect of rearing conditions was found only during the first evening milking after relocation. The group reared under the nursing cows had significantly lower milk volume in the first three min of milking and total milk yield as compared with the group of animals reared in loose housing with automatic drinker and hutches.

TABLE 1

The effect of relocation (control milking - before relocation; first, second, fifth and sixth milking after relocation) on milk yields and time of milking during evening and morning milking. Relocation was performed after control morning milking. Data are presented as lsmeans $\pm \mathrm{SEM}$

\begin{tabular}{|c|c|c|c|c|c|c|c|c|c|c|}
\hline \multirow{2}{*}{$\frac{\text { Order of }}{\text { Milking }}$} & \multicolumn{6}{|c|}{ Volume of milk, $\mathrm{kg}$} & \multirow{2}{*}{\multicolumn{2}{|c|}{$\begin{array}{c}\text { Total yield } \\
\mathrm{kg}\end{array}$}} & \multirow{2}{*}{\multicolumn{2}{|c|}{$\frac{\text { Milking time }}{\min }$}} \\
\hline & \multicolumn{2}{|c|}{$1 \mathrm{~min}$} & \multicolumn{2}{|c|}{$2 \min$} & \multicolumn{2}{|c|}{$3 \mathrm{~min}$} & & & & \\
\hline Evening & & & & & & & & & & \\
\hline control & $2.4^{\mathrm{a}}$ & 0.2 & $4.9^{\mathrm{a}}$ & 0.2 & $6.8^{\mathrm{a}}$ & 0.2 & $8.4^{\mathrm{a}}$ & 0.2 & $4.5^{\mathrm{a}}$ & 0.3 \\
\hline first & $1.4^{\mathrm{b}}$ & 0.1 & $3.7^{\mathrm{b}}$ & 0.3 & $5.7^{\mathrm{b}}$ & 0.3 & $8.0^{\mathrm{a}}$ & 0.3 & $5.3^{\mathrm{b}}$ & 0.2 \\
\hline fifth & $2.2^{\mathrm{a}}$ & 0.1 & $4.8^{\mathrm{a}}$ & 0.3 & $6.8^{\mathrm{a}}$ & 0.3 & $9.3^{\mathrm{b}}$ & 0.3 & $5.3^{\mathrm{b}}$ & 0.2 \\
\hline
\end{tabular}

Morning

$\begin{array}{lllllllllll}\text { control } & 2.6^{\mathrm{a}} & 0.1 & 5.8^{\mathrm{a}} & 0.3 & 8.2^{\mathrm{a}} & 0.2 & 11.3^{\mathrm{ab}} & 0.3 & 5.1^{\mathrm{a}} & 0.3 \\ \text { second } & 1.5^{\mathrm{b}} & 0.1 & 4.0^{\mathrm{b}} & 0.3 & 6.3^{\mathrm{b}} & 0.3 & 11.0^{\mathrm{a}} & 0.3 & 6.8^{\mathrm{b}} & 0.2 \\ \text { sixth } & 2.4^{\mathrm{a}} & 0.1 & 5.5^{\mathrm{a}} & 0.2 & 7.9^{\mathrm{a}} & 0.3 & 11.7^{\mathrm{b}} & 0.3 & 5.9^{\mathrm{c}} & 0.3\end{array}$

a,b,c different superscript of lsmeans within column for morning or evening milking indicate significant differences $\mathrm{P}<0.05$ 
TABLE 2

The effect of the type of housing of calves (hutches, nursing cows, automate feeder) on their later response to the change of milking environment in maturity. Data are presented as lsmeans \pm SEM

\begin{tabular}{|c|c|c|c|c|c|c|c|c|c|c|c|}
\hline \multirow{2}{*}{$\begin{array}{l}\text { Rearing } \\
\text { housings }\end{array}$} & \multirow{2}{*}{$\begin{array}{l}\text { Order of } \\
\text { milking }\end{array}$} & \multicolumn{6}{|c|}{ Volume of milk, $\mathrm{kg}$} & \multirow{2}{*}{\multicolumn{2}{|c|}{$\begin{array}{c}\text { Total yield } \\
\mathrm{kg}\end{array}$}} & \multirow{2}{*}{\multicolumn{2}{|c|}{$\frac{\text { Milking time }}{\min }$}} \\
\hline & & \multicolumn{2}{|c|}{$1 \mathrm{~min}$} & \multicolumn{2}{|c|}{$2 \mathrm{~min}$} & \multicolumn{2}{|c|}{$3 \min$} & & & & \\
\hline & control & $2.6^{\mathrm{a}}$ & 0.3 & $5.2^{\mathrm{a}}$ & 0.3 & $6.9^{\mathrm{a}}$ & 0.3 & 8.5 & 0.4 & $4.4^{\mathrm{a}}$ & 0.2 \\
\hline \multirow[t]{3}{*}{ Hutch } & first & $1.8^{\mathrm{Ab}}$ & 0.2 & $3.9^{\mathrm{Ab}}$ & 0.5 & $6.1^{\mathrm{Ab}}$ & 0.6 & $8.9^{\mathrm{A}}$ & 0.8 & $5.3^{\mathrm{b}}$ & 0.4 \\
\hline & fifth & $2.4^{\mathrm{a}}$ & 0.2 & $4.9^{\mathrm{a}}$ & 0.4 & $6.9^{\mathrm{a}}$ & 0.4 & 9.1 & 0.5 & $4.7^{\mathrm{ab}}$ & 0.2 \\
\hline & control & $1.8^{\mathrm{a}}$ & 0.2 & $4.3^{\mathrm{a}}$ & 0.3 & $6.3^{\mathrm{a}}$ & 0.3 & $8.1^{\mathrm{a}}$ & 0.2 & $4.3^{\mathrm{a}}$ & 0.3 \\
\hline \multirow[t]{3}{*}{ Nursing } & first & $0.8^{\mathrm{Bb}}$ & 0.1 & $2.5^{\mathrm{Bb}}$ & 0.4 & $4.3^{\mathrm{Bb}}$ & 0.5 & $6.9^{\mathrm{Ba}}$ & 0.7 & $5.5^{\mathrm{b}}$ & 0.3 \\
\hline & fifth & $2.3^{\mathrm{a}}$ & 0.4 & $5.0^{\mathrm{a}}$ & 0.8 & $6.7^{\mathrm{a}}$ & 0.6 & $9.6^{\mathrm{b}}$ & 0.6 & $6.4^{\mathrm{b}}$ & 0.6 \\
\hline & control & $2.6^{\mathrm{a}}$ & 0.2 & $5.4^{\mathrm{a}}$ & 0.3 & 6.9 & 0.3 & $8.7^{\mathrm{a}}$ & 0.3 & 4.9 & 0.4 \\
\hline \multirow[t]{4}{*}{ Feeder } & first & $1.6^{\mathrm{Ab}}$ & 0.2 & $4.3^{\mathrm{Ab}}$ & 0.3 & $6.3^{\mathrm{A}}$ & 0.3 & $8.6^{\mathrm{ABa}}$ & 0.3 & 5.1 & 0.4 \\
\hline & fifht & $2.1^{\mathrm{a}}$ & 0.2 & $4.7^{\mathrm{ab}}$ & 0.3 & 6.7 & 0.4 & $9.3^{\mathrm{b}}$ & 0.3 & 5.4 & 0.4 \\
\hline & Morning & & & & & & & & & & \\
\hline & control & $2.6^{\mathrm{a}}$ & 0.2 & $5.8^{\mathrm{a}}$ & 0.4 & $8.1^{\mathrm{a}}$ & 0.3 & 11.1 & 0.6 & $4.8^{\mathrm{a}}$ & 0.3 \\
\hline \multirow[t]{3}{*}{ Hutch } & second & $1.2^{\mathrm{b}}$ & 0.1 & $3.7^{\mathrm{b}}$ & 0.3 & $5.8^{\mathrm{b}}$ & 0.4 & 11.2 & 0.6 & $6.8^{\mathrm{b}}$ & 0.4 \\
\hline & sixth & $2.5^{\mathrm{a}}$ & 0.2 & $5.8^{\mathrm{a}}$ & 0.5 & $8.1^{\mathrm{a}}$ & 0.6 & 11.6 & 0.7 & $5.4^{\mathrm{a}}$ & 0.3 \\
\hline & control & $2.6^{\mathrm{a}}$ & 0.3 & $5.7^{\mathrm{a}}$ & 0.6 & $8.0^{\mathrm{a}}$ & 0.5 & 11.3 & 0.6 & $5.0^{\mathrm{a}}$ & 0.3 \\
\hline \multirow[t]{3}{*}{ Nursing } & second & $1.3^{\mathrm{b}}$ & 0.2 & $3.5^{\mathrm{b}}$ & 0.7 & $5.8^{\mathrm{b}}$ & 0.9 & 10.8 & 0.4 & $7.4^{\mathrm{b}}$ & 0.9 \\
\hline & sixth & $2.4^{\mathrm{a}}$ & 0.3 & $5.4^{\mathrm{a}}$ & 0.8 & $7.9^{\mathrm{b}}$ & 0.7 & 11.5 & 0.7 & $6.9^{\mathrm{b}}$ & 0.8 \\
\hline & control & $2.7^{\mathrm{a}}$ & 0.2 & $6.0^{\mathrm{a}}$ & 0.4 & $8.2^{\mathrm{a}}$ & 0.4 & $11.4^{\mathrm{ab}}$ & 0.4 & 5.5 & 0.5 \\
\hline \multirow[t]{2}{*}{ Feeder } & second & $1.9^{\mathrm{b}}$ & 0.2 & $4.8^{\mathrm{b}}$ & 0.4 & $6.9^{\mathrm{b}}$ & 0.5 & $11.1^{\mathrm{a}}$ & 0.5 & 6.4 & 0.5 \\
\hline & sixth & $2.4^{\mathrm{a}}$ & 0.2 & $5.4^{\mathrm{ab}}$ & 0.4 & $7.9^{\mathrm{ab}}$ & 0.5 & $11.9^{b}$ & 0.3 & 5.7 & 0.4 \\
\hline
\end{tabular}

a,b different superscript of lsmeans within column of single rearing system indicate significant differences $\mathrm{P}<0.05$

A,B different superscript of lsmeans within column among first milkings of different rearing systems for morning or evening milkings indicate significant differences $\mathrm{P}<0.05$ 


\section{DISCUSSION}

The relocation of dairy cows into unfamiliar surrounding induces total inhibition of oxytocin release and thus milk removal during the following milking (Bruckmaier et al., 1993; Rushen et al., 2001; Mačuhová et al., 2002). However, when animals were relocated to another milking place, milk removal was lower or even not disturbed (Tančin et al., 2000). In our experiment relocation did not negatively influence milk yield, probably because the cows were relocated several hours before the evening milking to have more time for adaptation to the new surroundings. However, the milk volumes measured during the first three min of the first evening and following morning milking after relocation significantly differed from the control and fifth milkings. The observations pointed to a delay in the commencement of milk ejection.

Our results showed the differences in the responses of dairy cows to the new place, which were related to their various rearing systems during the first two months of life. The cows raised by nursing cows were more sensitive to milking in a new place. We have already found large differences in the individual responses of cows to a new milking place (Tančin et al., 2000). We have shown that cows with a higher increase of milk yield between the first and second milkings after relocation had a higher increase of oxytocin release during milking. It was concluded that sensitivity to stress could be an important factor in the regulation of oxytocin release and that the rearing system could contribute to this sensitivity.

Recently we have found that animals with higher adrenal response to ACTH seemed to have less severe inhibition of milk ejection during milking in unfamiliar surroundings (Mačuhová et al., 2002). Housing conditions influence the ACTH-induced adrenocortical response in pigs and social contact and visual control play an important role in the development of these responses (Janssens et al., 1994). The delayed occurrence of milk ejection in cows raised by nursing cows could indicate that such animals are exploring the new situation more than cows from other groups. The results from open field tests reveal that calves from the nursing group moved less in an open field than their contemporaries from other groups (Brouček et al., 2000). The animals moving less in the open field test also had significantly lower ACTH-induced cortisol increase observed in heifers (Redbo, 1998) and pigs (Borell and Ladewig, 1992).

In conclusion, the first milkings after relocation negatively influenced the commencement of milk ejection, which should be taken into account by milkers to pay more attention to such cows. Also the individual response of the cows to relocation could be influenced by their rearing conditions in the early postnatal period of life. However, an endocrine study is needed to explain the possible effects of rearing conditions on milk removal in a new place. 


\section{REFERENCES}

Borell E., Ladewig J., 1992. Relationship between behaviour and adrenocortical response pattern in domestic pigs. Appl. Anim. Behav. Sci. 34, 195-206

Brouček J., Uhrinčat' M., Friend T.H., Arave C.W., Hanus A., Marenčak Š., 1999. Effect of different rearing during the milking period on growth and maze behaviour of dairy calves J. Dairy Sci. 82, Suppl. 1, 77 (Abstr.)

Brouček J., Uhrinčat' M., Friend T.H., Arave C.W., Mihina Š., Hanus A., Kišac P., 2000. Effect of rearing method of calves prior to weaning on subsequent open-field behavior at 28 week of age. J. Anim. Sci. 78, Suppl. 1/J. Dairy Sci. 83, Suppl. 1, 35 (Abstr.)

Bruckmaier R.M., Blum J.W., 1998. Oxytocin release and milk removal in ruminants. J. Dairy Sci. 81, 939-949

Bruckmaier R.M, Schams D., Blum J.W., 1993. Milk removal in familiar and unfamiliar surroundings: concentrations of oxytocin, prolactin, cortisol and $\beta$-endorphin. J. Dairy Res. 60, 449-456

Janssens C.J.J.G., Helmond F.A., Wiegant V.M., 1994. Increased cortisol response to exogenous adrenocorticotropic hormone in chronically stressed pigs: Influence of housing conditions. J. Anim. Sci. 72, 1771-1777

Mačuhová J., Tančin V., Kraetzl W.D., Meyer H.H.D., Bruckmaier R.M., 2002. Inhibition of oxytocin release during repeated milking in unfamiliar surroundings: importance of opioids and adrenal cortex sensitivity. J. Dairy Res. 69, 63-73

Redbo I., 1998. Relations between oral stereotypes, open-field behaviour and pituitary - adrenal system in growing dairy cattle. Physiol. Behav. 64, 273-278

Rushen J., Munksgaard L., Marnet P.G., de Passillé A.M., 2001. Human contact and the effects of acute stress on cows at milking. Appl. Anim. Behav. Sci. 73, 1-14

SAS, 2001. Institute Inc., Cary, NC 27513

Tančin V., Bruckmaier R.M., 2001. Factors affecting milk ejection and removal during milking and suckling of dairy cows. Vet. Med.-Czech 46, 108-118

Tančin V., Kraetzl W.-D., Schams D., Bruckmaier R., 2001. The effect of conditioning to suckling, milking and of calf presence on the release of oxytocin in dairy cows. Appl. Anim. Behav. Sci, 72, 235-246

Tančin V., Kraetzl W.-D., Schams D., Mihina Š., Hetényi L., 2000. The oxytocin secretion and milk letdown during milking immediately after the change of milking and housing conditions. Vet. Med.-Czech 45, 1-4

Zimmerberg B., Rosenthal A.J., Stark A.C., 2003. Neonatal social isolation alters both maternal and pup behaviours in rats. Dev. Psychobiol. 42, 52-63

\section{STRESZCZENIE}

\section{Wpływ zmiany stanowisk udojowych na wydzielanie mleka przez krowy pierwiastki utrzymy- wane w różnych warunkach we wezesnym okresie odchowu}

Celem doświadczeń było sprawdzenie czy zastosowanie różnych systemów odchowu cieląt ras mlecznych przed odsadzeniem może wpływać na późniejszą ich reakcję na zmiany miejsc przy udoju. W okresie wstępnym 96 jałówek holsztyńskich, podzielonych na 3 grupy po 32, odchowywano w różnych warunkach utrzymania przed odsadzeniem w 60 dniu życia. Przez pierwsze dwa miesiące życia cielęta grupy 1 utrzymywane były w pomieszczeniu wolnostanowiskowym i pojone $\mathrm{z}$ au- 
tomatycznych poideł preparatem mlekozastępczym, cielęta grupy 2 - w indywidualnych klatkach i pojone $\mathrm{z}$ wiader preparatem mlekozastępczym, grupy 3 - w pomieszczeniu wolnostanowiskowym żywione przez krowy-mamki. Po odsadzeniu aż do wycielenia wszystkie zwierzęta odchowywane były w jednakowych warunkach utrzymania i żywienia, stosowanego w pomieszczeniach wolnostanowiskowych. Spośród wszystkich jałówek wybrano następnie 33 sztuki (13 pochodzących z grupy 1, 12 - z drugiej i 8 z trzeciej) do właściwego doświadczenia, na krowach mlecznych. Po rannym doju w pomieszczeniu wolnowybiegowym krowy przeprowadzano na stanowiska uwięziowe, gdzie były dojone. W obydwóch systemach udoju zastosowano te same wskaźniki oceny. Ilość mleka otrzymana w ciagu pierwszych trzech minut doju była mniejsza pierwszego wieczoru i następnego ranka po przemieszczeniu krów $(\mathrm{P}<0,05)$. Później, ujemny wpływ zmiany stanowisk był większy u krów z 3 grupy odchowu (karmionych przez krowy-mamki) w porównaniu z pozostałymi, lecz tylko podczas pierwszego wieczornego udoju $(\mathrm{P}<0,05)$.

$\mathrm{W}$ podsumowaniu autorzy stwierdzają, że zmiana stanowisk opóźnia rozpoczęcie wydzielania mleka, i że opóźnienie wydzielania mleka może być pominięte, jeśli weźmie się pod uwagę warunki utrzymania krów we wczesnym okresie odchowu. 